Martin Ruck, Michele Peterson-Badali and Michael Freeman

(eds) Handbook of Children's Rights: Global and Multidisciplinary Perspectives.

London \& New York: Routledge, Chapter 13, pp 203-220.

This version has more references than the final version

\title{
Health and children's rights
}

Priscilla Alderson

The Convention on the Rights of the Child (UNCRC, UN 1989) is imbued with respect for every child's embodied worth and dignity, and with the social, economic and political means of promoting these. Ratified in every country expect the US, the UNCRC shows how health and healthcare weave into practically every human right. The Committee on the Rights of the Child (2013) analyses this in detail, because all children's rights are interdependent and indivisible. The Committee regards "health as a state of complete physical, mental and social well-being and not merely the absence of disease or infirmity" following the World Health Organisation (WHO, 1946). The African Charter on the Rights and Welfare of the Child (African Union 1990, Article 14) adds "spiritual health' and like the UNCRC (Article 24c) directly links health to "nutritious food and safe [or clean] drinking water" and the right to "adequate health care".

The great international rights treaties (UN 1948; EC 1950), echoed in the UNCRC and African Charter, emerged from World War II and the holocaust. The United Nations realised the extent both of frail human physical vulnerability to suffering, illness and death, and of the human capacity to oppress and torture others. They agreed therefore on the need for formal global human rights standards to protect the vulnerable and to prevent oppression and injustice.

The human vulnerability of children and adults binds us all together in positive ways, as the source of our understanding of empathy, compassion, interdependence and solidarity (Herring, 2012), the grounds of human rights. The years of childhood dependence reinforce these human ties, positively through loving care, negatively when children are abused or neglected. Besides being legal concepts, human rights emerge from physical and psychological needs - for an adequate standard of living, and freedom from physical and mental abuse. Rights to life, liberty and security of person all affect health, as do the freedoms of information, expression, association, social inclusion and non-discrimination. These rights are the deeply experienced and enacted means of protecting and promoting physical, mental, social and spiritual health and wellbeing.

Among countless examples of health pervading the UNCRC is Article 31, on the child's rights to rest and leisure, and to engage in play and recreation. These rights promote health through children's quiet times and their lively activities and friendships, which help to reduce and prevent exhaustion, stress, obesity, loneliness and depression. The rights relate to time and space. Schools take up more of children's time with long hours of study and homework and stressful tests, while many working children around the world have to work longer hours for smaller wages. Both rural and urban public spaces, including woods, fields and rivers, parks, playing fields, school playgrounds and youth clubs, are being enclosed and privatised (Pearce, 2012). In crowded cities, homes are becoming smaller with many children living in high-rise flats (Minton, 2012), so that these open public spaces become ever more vital activity and meeting places, necessities not luxuries for children and young people and for healthy communities. 
One version of rights is "my rights", selfish individualism and protection of private property. The UNCRC Preamble endorses the contrasting version of "our" equal rights, "the equal and inalienable rights of all members of the human family [as] the foundation of freedom, justice and peace in the world". Free open playgrounds and shared piped water benefit every local child, their health, families and communities, their present and future.

This chapter considers two main areas of health-related rights, based on Article 24 (UNCRC 1989): "the right of the child to the enjoyment of the highest attainable standard of health"; and the right to the highest attainable health care services with "facilities for the treatment of illness and rehabilitation of health". The concluding section considers why so many children's health-related rights continue to be neglected, and ways forward to increase their promotion.

\section{The highest attainable standard of health}

There is no "right to health", just as there is no right to love, because health and love cannot be willed or enforced. No one can tell a child dying of cancer, "don't worry you have the right to health". Yet the child should be assured "we will try to give you the best possible or the highest attainable standard of health" within the limits of terminal cancer, such as with good nursing and pain relief. On loving care, parents cannot be taken to court for not loving their child enough. However, the courts can protect children's rights not to be neglected or abused by their parents, behaviours which the parents have the power to change. One example is if parents refuse to consent to life-saving treatment for their child. In this way the courts give realistic, practical support to children's health. And the UNCRC Preamble speaks of children's need for respect for their "worth and dignity", the basis of healthy living, and how all the Articles aim to support "an atmosphere of happiness, love and understanding" in families.

The UNCRC promotes justice by expecting that governments should not leave some of their children to be neglected and unhealthy, while others have privileged standards of health. Every child should be able to enjoy the "highest attainable standard of health", which that state can support. Yet the "attainable standard of health" varies between the wealthier or minority world (about $17 \%$ of people in the world) and the majority poorer world, when wealthier states can support much higher standards of living and health and healthcare than poorer states can. The UNCRC Article 24.4 promotes justice through advocating "international co-operation" to achieve the health-related rights particularly in "developing countries". The UNCRC is concerned explicitly or implicitly with many social determinants, or conditions, that can benefit or harm children's health. Determinants include adequate family income, road safety, vaccination programmes, clean air and many other health and safety measures.

Even in rich countries such as Britain, one quarter of children live in poverty and many others live in borderline poverty (UNICEF 2014). The "austerity" programme has disproportionately affected children, with "a great leap backwards" in child health and wellbeing. ${ }^{1}$ Every day, five more young children die in the UK than in Sweden. ${ }^{2}$ Many health outcomes for British children remain poor (Marmot et al. 2013), and a baby girl born into a poor area may live 15 fewer years in good health than one born in a privileged area. $^{3}$ 
Poverty and malnutrition "stunt" children's physical, mental and social development and wellbeing. Between 100 and 140 million children have vitamin A deficiency, a major cause of blindness, illness and early death (lannott et al., 2013). One disadvantage can lead on to others (Doman and Woodhead, 2015). ${ }^{4}$ Children's own poor diet and hunger during severe food shortages appear to affect their grandchildren's metabolism through epi-genetics (Pembrey et al., 2006). To promote child health-related rights today sows the seeds for healthy societies tomorrow and helps to prevent conflict, suffering and wasted lives (Bryant and Raphael, 2015). There are complex interactions between everyday life and children's health. For example, in England house prices are soaring and families who cannot afford the rising rents keep being moved into lower quality housing away from their friends, schools and neighbourhoods, greatly disrupting children's sense of secure wellbeing and their mental health (reviewed later).

The USA ranks at or near the bottom among the 34 wealthiest countries "on nearly all indicators of mortality, survival and life expectancy". ${ }^{5}$ The indicators include living conditions likely to undermine health and wellbeing. There is the highest teenage birth-rate, almost the lowest survival rate of baby girls, the highest proportion of single parent families, and more than a fifth of the children live in poverty.

In past decades, numbers of children and adults in prison have soared in some countries. Many young prisoners have had childhoods of severe abuse and neglect, and are also abused in prison, and many have serious mental illness and learning difficulties, with very high rates of self-harm. They need to be in remedial settings instead of punitive ones (Willow 2015). The USA imprisons almost five times as many people per capita as most other rich democracies, including 3,000 mainly black children and young people. Thousands of them are serving life sentences with no parole, which means death in prison. Often sentenced when they were aged 13 or 14 or younger, they may spend years in windowless rooms in solitary confinement, without adequate healthcare for injuries and illness (Stevenson 2014).

The UNCRC aims to support parents and families, not to control them. The Convention respects women's rights when it avoids saying that babies have "the right to be breastfed", which would overrule women's control over their own body. Instead, states should ensure that everyone "and in particular parents and children; are informed, have access to education and are supported in the use of basic knowledge of child health and nutrition, the advantages of breast-feeding, hygiene and environmental sanitation and the prevention of accidents" (Article 24, 2e). Potential controls on adults and children, that would deny their freedoms, are turned into rights to education and practical support with the duty on state parties to provide these.

States should provide adequate "primary health care", "combat disease and malnutrition", "ensure appropriate pre-natal and post-natal health care for mothers", "develop preventive healthcare, guidance for parents, and family planning education and services" (UNCRC, Article 24, 2 b, c, d, f). Family planning (Article 24f) and population control can seem anti-child in preventing births. Alternatively, it is prochildren in seeking to reduce the immense problems of over-population on a finite planet, and to promote the health and potential of all children, when every child is wanted and cherished. Over the past 15 years in China, infant mortality has halved, and the one child policy may have contributed to this progress. The Chinese government's annual budget of about $£ 230$ billion only partly covers everyone's healthcare costs, and there are frequent riots because of the high charges for medicines. ${ }^{6}$ 
"Traditional practices prejudicial to the health of children" mainly meaning female genital mutilation (FGM) should be abolished (UNCRC Article 24.3). Children's physical and mental health, their rights to bodily integrity and protection from harmful practices can conflict with the rights of people "to enjoy their own culture" (UNCRC Article 30) as shown by debates about FGM and about degrees of physical punishment (debated, for example, by Sloth-Nielsen and other authors in Freeman, 2012).

States should address "the dangers and risks of environmental pollution" (Article 24c), a clause that is rapidly growing in importance, given the dangers to air, water and land. Air pollution from China to Mexico damages the health of children and adults in cities, while many industries waste water and pollute wide areas. ${ }^{7}$ Greater use of pesticides increases resistant insect strains, which are met with higher doses of chemicals. Although the carcinogenic pesticide chlordecone was banned in the USA in 1976, it was found to contaminate Martinique wildlife, but it continued to be used until 1993 to protect bananas in Martinique. The French West Indies export 270,000 tonnes of bananas a year to Europe, and the chlordecone is expected to pollute local land, fresh and sea waters and fish for the next 700 years. Families are advised which foods to avoid, though vision and psycho-motor impairments have been found in 1,000 babies on the islands. ${ }^{8}$

The greatest threat is from the greenhouse gases that cause global warming, which is already associated with an estimated annual death rate of from 150,000 to five million, ${ }^{9}$ mainly in countries with especially high populations of children. The world is warming unevenly with a possible rise of up to $10^{\circ} \mathrm{C}$ higher in already hot areas parts of the world within the next hundred years, ${ }^{10}$ and within the lifetime of many of today's children. Work to reduce climate change depends on recognising the shared equal health-related rights of "all members of the human family".

The UNCRC's emphasis on basic healthcare reflects the needs of the great majority of the world's children for protection from malnutrition, dehydration and "minor" infections, which can be prevented and cured but which continue to kill millions of children each year.

\section{Problems of violence}

Steven Pinker (2011) has argued that the world is now less violent and far more peaceful, with less military conflict, homicide, genocide, torture, and cruelty to children than in past centuries. However, Pinker concentrates on deliberate actions. In some ways, the world is far more violent today than in the past, often impersonally, through structures (Lewis 2015). Although this suffering may be unintended, much could be avoided and prevented.

While kindness towards many children may have increased, there is still the mass illness, injury, exploitation and death of countless children through violence (UN Secretary General, 2006), through neglect and abuse, through the slave labour of 8.4 million children, ${ }^{11}$ the many children among the 2.48 million people killed in road traffic incidents each year, ${ }^{12}$ and the numbers killed or seriously harmed by pollution and by poverty. If the poverty line were set at $\$ 3.60$ ( $£ 2.40)$ a day, about 3.5 billion people would be living in poverty, and 500 million more of them would be living in extreme poverty than there were in $1981 .{ }^{13}$ Each day around 21,000 children die, many for lack of basic healthcare. 
Global warming, already estimated to cause over 150,000 deaths annually, has violent effects in extreme and increasing floods, hurricanes and droughts (Carty, 2012). ${ }^{14}$ Drought and hunger are spreading through many countries including through eastern Pakistan, northern India and into Bangladesh, where 600 million people live. Millions of wells and aquifers are being over-pumped so that far more fresh water is used than is being naturally replaced. ${ }^{15}$ Within the next ten years, nearly three billion people in 48 nations are predicted to experience chronic water scarcity. ${ }^{16}$ In wells across Asia, there are very high levels of fluoride and arsenic affecting many millions of people in "the world's largest mass poisoning" which is causing children to become misshapen and disabled (Pearce 2007, 72-77). Another silent violence, which attacks children's minds and bodies and is connected to disturbed behaviours and learning difficulties, is leaded petrol that is still used in some countries, and the flaking, leaded paint work in many US tenement blocks that is breathed in and sucked in by young children (Nadesan, 2010).

Almost everyone is drawn into unhealthy and even deadly routines unwillingly or unknowingly when it is hard to avoid buying clothes that have been made in Asian sweat shops. There, without adequate health and safety regulations, child and adult workers endure fatigue, illness, harassment, accidents, sometimes fires and the collapse of buildings. There is also the violence of forcing millions of people off their land, and away from their farms, into fetid city slums (Pearce 2012, Roy 2014).

Among the world's refugees who are trying to escape from violence or extreme poverty are numerous children. Half of the millions of refugees from Syria are children. ${ }^{17}$ Bribes and subsidies in government arms deals ${ }^{18}$ help to flood the world with "legal" arms, but from the seven to eight million weapons sold each year for over $\$ 1.5$ trillion, it is estimated that almost one million weapons are stolen or lost into illegal systems. Today's lighter weapons more readily arm child soldiers increasing the risks that children will be forced into armies where they are highly likely to suffer from hunger, exhaustion, infection, terror, disabling or lethal wounds and post traumatic stress disorder (Honwana and De Boeck 2005; Bourke 2014).

In 2012 alone, almost a trillion dollars were funnelled out of the poorer countries, through crime, corruption and tax evasion, and more of these funds flow out of Africa than flow in through trade and aid. ${ }^{19}$ Global corruption in the arms industries is estimated to cost $\$ 20$ billion per year, diverting much needed funds away from health care. India has the highest number of poor children, and is the highest spender on arms. And the effects of armed violence cost Africa an estimated \$1 billion a year. Each minute in the world on average one person is killed by a weapon. ${ }^{20}$

Wars are now conducted mainly in urban areas and in extremely poor countries, where most of the casualties are civilians. In Iraq, where 45 per cent of the people were aged under 15-years, sanctions during 1993-2003 were estimated to have killed 500,000 children. ${ }^{21}$ During 2003-2011, there were almost one and a half million child and adult war-related deaths. Jeff Lewis (2015) noted that Steven Pinker vastly underestimated deaths in Iraq, most of which were "secondary", from effects after the war through untreated disease, injury, lawlessness, suicide and through the lifesustaining social fabric having been destroyed. Every day in 2011, on average 100 Iraqi children died from malnutrition, lack of health services, and from landmines and poisons leaked from weapons. There are also high rates of child cancers and of malformed babies. ${ }^{22}$

Avoidable violence has increased compared to 50 years ago, in relation to our knowledge, technologies, choices and policies. On knowledge, constant news reports ensure that we immediately know about wars and other major disasters, 
whereas in the past we were often unaware. Today we have the technologies, wealth, transport and resources to supply everyone with healthcare, education, clean water, food and shelter, yet we choose to divert resources elsewhere, such as into the arms industry. And dominant policies in the ever more closely-knit global village increase inequality and debt, and reduce the public services, which children especially need (Woodhouse, 2010).

The global systems of poverty and violence damage children's health in several major ways: they jeopardize children's present health, education and standard of living; they therefore reduce children's abilities to build better, healthier societies in future; and they erode the infrastructure including health services, and the trust, justice and democratic systems on which healthy societies depend.

\section{Rights to the highest attainable healthcare services and facilities for the treatment of illness and rehabilitation of health}

To become a patient is not a formal right, but it is a necessary step towards the right to the best attainable healthcare. There are great differences in how children are or are not treated as patients or perceive themselves as patients (reviewed more fully in Alderson 2014). The borderlines between health and illness are drawn differently in the minority and majority worlds, as shown in the following examples.

Talcott Parsons (1951) identified disease as bodily dysfunction, whereas he saw being ill and being a patient as social roles. The patient or sick role involves four expectations: exemption from normal role responsibilities; legitimation often by a doctor; wanting to get better; and seeking and cooperating with technically competent help.

Minority world children with brief illness, who might like "legitimation" to rest in bed and be "exempted" from normal responsibilities, tend nowadays to be sent off to school with their antibiotics and have to behave "normally". Many children with lifethreatening, long-term illness, such as diabetes or cystic fibrosis, thanks to medication, are very pleased to live thriving, active, "normal" lives. Much corrective surgery is greatly valued by children such as for congenital heart disease or cleft palate, transforming them from sick or disabled childen into healthy ones.

There is uncertainty about when children's seemingly abnormal feelings and behaviours come with a normal range, or should be corrected, or punished, or are forms of illness. Identified psychiatric disorders have multiplied in recent decades (APA, 2013). Sales of medication to treat emotions and behaviours have also soared (Bakan, 2012; Mills, 2012) ${ }^{23}$ alongside research to develop the treatments (Rose and Rose 2014). In Britain, the reported incidence of hyperactivity, autistic spectrum, depression, anorexia ${ }^{24}$ and many other problems has increased, with one in ten children aged under-15 years having diagnosed mental health problems, including over 8,000 aged under-10 years, as well as 72 per cent of children in care, and 95 per cent of imprisoned young offenders. ${ }^{25}$ One in every 12 to 15 young people deliberately self-harms, with a steep rise in hospital admissions and reported suicide attempts over the past decade. More than half of all adults with mental health problems were diagnosed in childhood, when less than half were treated appropriately, so neglect in childhood can have far-reaching effects. Yet child and adolescent community mental health services have been cut, by up to 94 per cent during 2011-2014 in Britain's second largest city. ${ }^{26}$ Thousands of nurses were dismissed, ${ }^{27}$ so that many untreated problems become more serious and expensive 
to treat. Children in great need, such as after attempted suicide, are taken to crowded Accident \& Emergency departments where the staff do not have the skill or time to help them. Children who are thought to be a danger to themselves or others may be detained in police cells, ${ }^{28}$ or sent hundreds of miles away to where a hospital bed can be found, frequently in wards for very disturbed adults.

UNCRC Article 25 enshrines the right of children when they receive "care, protection or treatment [for] physical or mental health, to a periodic review of the treatment provided for the child and all other circumstances relevant to his or her treatment". This important right helps to protect children from sub-standard care, to maintain general standards, and to use complaints to inform and improve future services. To be a real right, if the review reveals serious problems that the staff will not correct, then children and parents must be able to appeal for legal support for their complaint (UNCRC Article 40). However, children usually need funded support and their access to legal aid has been cut. ${ }^{29}$

Each year, screening results in millions of possibly healthy children being identified as patients who receive healthcare services, though not always willingly. There has also been a great increase of screening of the "worried well"; 100,000s babies are screened to detect the very few who have, for example, cystic fibrosis, in the belief that treatment is most effective when it begins as early as possible. Those who would have died as children or teenagers can now expect to live into their 40s or longer, which seems a miracle to affected families, who see their right to the highest attainable health and healthcare more than justifies the mass neonatal screening. However, screening of children for late-onset genetic-related conditions such as breast cancer or Huntington"s chorea is more controversial. Not only will the conditions develop years later in adulthood, but there is no cure or prevention (apart from a double mastectomy in adulthood for breast cancer). Should healthy children be haunted with such longer term future fears, which could complicate their prospects for marriage/partnership and for having their own children? (Clarke and Ticehurst, 2006; Evans et al., 2011). If children are tested and found to be carriers of recessive genetic conditions, when they will not have cystic fibrosis or sickle cell themselves, for example, but might pass the illness onto their children, when should they be informed? Rights to information can conflict with rights to privacy and the freedom not to be burdened with unwanted fears that have no remedy.

While many children and parents value their healthcare treatments, some find that treatments are useless or harmful, or they do not want to be treated as patients, while others remain in great unmet need. Millions of majority world children who are severely ill and urgently need medical treatment have no hope of becoming patients in terms of receiving diagnoses and formal healthcare. About one in every three births is not registered, so that states cannot properly respect these children's rights to state services and care. An estimated .37 billion children have no access to professional health care.

Excellent healthcare services do not guarantee excellent standards of health. The US has the highest healthcare budgets and some of the best doctors, nurses and hospitals in the world, but one in four children were denied healthcare in $2007^{30}$ and although Obamacare has improved matters, it leaves many children under-insured. ${ }^{31}$ Antenatal, normal birth and newborn care cost an average $\$ 30,000$ in 2013 and, for a caesarean section, $\$ 50,000 .^{32}$ Commercial insurers paid an average of $\$ 18,329$ and for caesareans $\$ 27,866$, leaving families to meet the difference, which bankrupted many of them. Despite the highest healthcare costs in the world, 50 per 
cent more babies die in the US during their first day of life than in any other industrialized nation surveyed. ${ }^{33}$

Medicine and nursing are international disciplines, and major hospitals everywhere are run on similar lines, so that all countries can benefit from the knowledge and skill. Yet expensively trained healthcare staff tend to move from poorer countries, ridden with tropical diseases, where there is much greater need and up to half the population may be children and young people, into richer counties where children may be one fifth or less of the population. "There are more nurses from Malawi in Manchester than in Malawi and more doctors from Ethiopia in Chicago than in Ethiopia" (Khor, 2006).

A similar imbalance is when pharmaceutical companies invest in researching profitable medicines, such as for behavioural problems of relatively healthy, minority world children (Bakan 2012), but neglect research on tropical diseases that endanger millions of people, especially young children who lack immunity and are most likely to be disabled or to die from infections. The huge potential market for medicines in the majority world is largely closed by poverty, and global drug companies sue firms in India, trying to prevent their efforts to meet the great need by producing cheap versions of costly medicines. ${ }^{34}$ There is also less regulation in many countries as well as over the internet, with higher risks of fake, contaminated and out-of-date medicines, of inaccurate over-prescribing by under-trained doctors, and misuse of medicines by everyone who cannot read the instructions. Worse still, leading pharmaceutical corporations have bribed thousands of Chinese doctors to overprescribe and overcharge for drugs, ${ }^{35}$ especially for cancer treatments, when desperate parents will accept almost any medical advice for their sick child.

Authorities and hospitals that rely on donations from these firms dare not prosecute them.

The 2014-2015 Ebola epidemic in West Africa revealed missing health services in areas with the highest maternal and perinatal mortality rates in the world. ${ }^{36}$ The rates had been improving and each year across the region, the estimated 800,000 women who give birth became more likely to receive free care in a health centre assisted by skilled staff, to promote babies' right to life. However, there are still very limited healthcare and sanitation services, basic resources such as clean water and soap, and limited common knowledge about how to prevent and treat diseases. Infection spreads rapidly among malnourished people with low resistance to disease living in crowded slums. During the Ebola epidemic, when people dared not touch them and they were afraid to go to a hospital, woman had their babies unaided at home or in the streets. ${ }^{37}$ Hospitals came to be feared and avoided as death houses, so that rates of untreated serious and fatal disease rose. Schools, markets and farms closed down and hunger increased, while many children who were orphaned by Ebola were feared and isolated. Ebola revealed the whole unequal, unjust global healthcare system, most extreme in Africa, where up to half the citizens in some states are aged under-15 years. ${ }^{38}$ UNCRC Article 24.4 requires states "to promote and encourage international co-operation" to respect all children's health-related rights; "particular account shall be taken of the needs of developing countries".

From numerous examples of severe illness, an estimated four million people in Nigeria alone currently have extremely painful sickle cell disease, and each year over 150,000 affected children are born, while 100,000 affected children and adults die. ${ }^{39}$ "About 100,000 individuals in the USA and millions more worldwide have sickle cell disease, which leaves them at risk of strokes, disability and premature death. [It] is the most common genetic disorder affecting African-American individuals [as well 
as] those from other ethnic and racial backgrounds" (Wang et al., 2013). They tend to live either in poorer countries, or in poorer communities in rich countries, yet they have vital and costly healthcare needs.

Sickle cell is a recessive genetic disease (both parents have to be carriers, though they may not have the full disease or be aware that they are carriers), and higher numbers of affected people increase the chance of their intermarriage. During the 1970s, the needs of people with another severe, recessive, genetic blood disorder, Thalassaemia, were overwhelming health service budgets in southern Cypress. All the authorities, including the churches, promoted pre-conceptual prevention. Individuals are tested and counselled before marriage, so that identified carriers have the informed choice to avoid marrying one another, and to avoid the distress of having affected children or making painful decisions about prenatal testing and terminations. ${ }^{40}$ This compassionate and cost-effective work very urgently needs to be organised wherever there are high rates of severe recessive genetic disorders.

\section{Consent to medical treatment and research}

Central to Locke's and Kant's concepts of modern rights is the self-determining autonomous "Man". His autonomy in decision-making is so deeply assumed that it is not mentioned in the great rights treaties, but is phrased as negative rights to noninterference with private life and implicitly supported byu all other rights (UN 1948; EC 1950). Children's rights are both weakened and strengthened by Article 12, which respects three levels of children's views: first are children's rights to form views and second to express them. Yet babies form and express views, such as when they are tired or hungry or happy (Alderson et al., 2005), no one can stop them, so are these really rights or simply activities? Third children have the right that their views are "given due weight in accordance with the age or maturity of the child". This right is so highly qualified and dependent on adults' assessments that its status as a right is uncertain.

UNCRC does not mention "decision making". Yet it respects extra legal provision made by states, which is "more conducive to the realization of the rights of the child" than the Convention (Article 41). English common law, which influences the 53 British Commonwealth countries, respects a fourth level: the right of "Gillick competent" children to make their own decisions. ${ }^{41}$ Children of unspecified age can give legally valid consent, such as to medical treatment, when they are able to make an informed and enlightened decision and their doctor deems they are competent. Empirical research demonstrates how children are involved in minor though not major medical decisions about cancer care (Coyne et al., 2014), and how some experienced younger children can be competent decision-makers about major surgery and diabetes care (Alderson, 1993; Alderson et al., 2006). If children are not happy about chemotherapy or surgery intended to save life or prevent serious disability, usually great efforts are made (in Britain) to inform and involve them, sort out fears and misunderstandings, negotiate as much as possible, and avoid forcing treatment against fearful resistance. Complications about legal restrictions on children's right to consent to treatment but not to refuse it are reviewed in detail elsewhere (Alderson, 2012).

Healthcare offers children unique respect for their consent. Children's rights are sometimes divided into the "3 Ps", provision, protection and participation, which all clearly relate to health and healthcare. Powerful dyads may be set up: the providing 
adult and the needy child; the protecting adult and the victim child; the more mutual equal partnership of participation between adults and children or young people. Providing professionals such as teachers, and protecting ones such as social workers, may override children's and parents' views and decisions, and claim that only professional experts can determine the child's best interests. Teachers serve groups of children, and must balance individual with group rights, which further downplays each child's own views. Teachers may see talking to children about rights as a way of educating children but not necessarily of listening to them or heeding their views. Social workers may want to protect children, and themselves, from the stress, anxiety and risks of sharing full yet distressing information and of children making decision that might go wrong, or bring them into danger, or for which they might be blamed. In contrast, doctors who plan risky treatment for an individual child are legally obliged in many countries to give detailed information and to respect the child's and/or parent's informed and voluntary or unpressured consent. In English law, unlike other professionals, doctors cannot override families' decisions without going to court and obtaining legal authority.

Healthcare and medical research ethics thus set the highest standards of respect for children's rights, because of the high direct and obvious risks if a child's body is harmed. Voluntary consent as the central human right was defined in the Nuremberg Code (1947): The person concerned should have sufficient information and freedom from pressure to be able to make a free, "understanding and enlightened decision". Nuremberg was agreed (like UN, 1948; EC, 1950) in reaction to abusive medical research during the holocaust (see the beginning of this chapter). Informed consent to treatment involves knowing the hoped-for benefits, the methods and processes, risks and discomforts, any alternative treatments, and the likely effects of the continuing problem if it is not treated (adapted from Declaration of Helsinki, WMA, 1964/2013). The discussion and relationship between the doctor and child patient or research participant, in their aims, topics, methods, processes, values and outcomes, are all supposed to centre on the child's and/or parent's autonomy, qualified by concern for the child's "best interests" and "evolving capacities" (Articles $3,5,18)$. There should be honesty about risks, caution about benefits, and deference to the patient's and/or parent's decision. Children with long-term conditions often know much from experience about the bodily problems to be treated, and the desired balance between the need and hoped-for benefits of treatment against the harms and costs (Alderson 1993).

Uniquely in English law, doctors are ultimately accountable to the courts not for making a correct decision, but for ensuring that the patient and/or parent was able to make an informed and voluntary decision. The doctor cannot claim that the parents were incompetent to decide, as teachers and social workers might do, but must inform families adequately. Doctors who act without consent (unless they have permission from the High Court and except after compulsory psychiatric admission) can be tried for negligence (for not informing patients sufficiently) or for assault (touching the person without valid consent), which protects children's rights.

Knowledge and treatments developed through medical research have greatly supported children's health-related rights, and have lengthened and enhanced the lives of very many. However, research can also challenge children's rights. More clinical trials are now conducted in majority world countries, raising hopes of introducing better healthcare there. Nevertheless, new medicines continue to be too expensive, and companies are urged to lower prices to ensure that those who helped with the research may benefit from the results. There are concerns that the 
trials are being outsourced to poor countries because regulation is more lax, and the people are less aware about medical ethics and their right to give or withhold informed consent (Kolch et al., 2010). Parents are eager to volunteer their children for research, when it is their only hope of obtaining treatment, and they are left unaware of the risks. Lax standards of regulation and legal recompense are illustrated by 15 years of delay after a trial of Trovan to treat meningitis in Nigeria, when children were disabled or died. The company eventually settled with a few of the families out of court and Trovan has not proved to be effective or been licensed for sale. ${ }^{42}$

British ethics guidance $(\mathrm{RCPCH}, 2000)$ insists that children should be involved in medical research only if the research cannot equally well be done on adults, and if the findings are intended to benefit children as a group. However, US guidance does not respect these protection rights. In the US, children are recruited simply to increase numbers of subjects in adult trials, with no guarantee that they will be studied as a separate group in order to benefit future child patients, and there are lower standards for testing new treatments (Ross, 2006).

There are complications about children's rights to give or withhold informed consent to mass biomedical research, when survey data or human tissue or genetic material may be used in unknown ways by future research teams (see review in Alderson and Morrow, 2011; Rose and Rose 2014).

The medical journals regularly debate fraud and how commercial interests distort research funding and agendas, bioethics committee judgements, and peer reviewing for journals. ${ }^{43}$ Yet over past decades, many doctors have gradually accepted that codes of ethics and consent protect not only patients' rights, but also doctors, researchers and high standards of treatment and research.

\section{Ways forward to promote children's health-related rights}

Are children's health-related rights legal, moral or political? Some analysts deny that healthcare is either a legal or a moral human right (Buchanan, 2015). Health and healthcare are then seen as commodities to be bought and sold in contracts between free agents.

Millions of children have no practical legal right to healthcare when the services do not exist. Yet by ratifying the UNCRC and the African Charter, in principle governments support the legal right to the best attainable healthcare for every child, and the state's duty to provide it.

Children's healthcare can be defended as a moral right in terms of social justice, non-discrimination and equity, the relief of avoidable suffering, and governments' primary duty to defend their citizens against dangers, which include, for example, severe infections. To avoid violating others' rights by passing on lethal infections, people must seek treatment such as for Ebola, HIVIAIDS, TB and typhoid. Measles can be another deadly infection. If people cannot afford necessary healthcare and vaccinations, then states have some obligation to provide these along with public information and measures to promote health. Most of all, states must support their children's health before, during and after birth and through childhood, if they are to ensure that there will be healthy workers and parents in future who will sustain society and not be sick, costly burdens on the state. 
Besides having legal and moral weight, children's rights are also highly political when they concern public control over power and resources. Three broad ways of controlling the politics of healthcare are the market, philanthropy and the state.

First, the market leads some areas of healthcare, such as providing medicines and technology, and it can achieve high standards in private hospitals. However, as earlier examples showed, healthcare markets can be the most costly and the least effective, especially for children and other no-income and low-income groups who cannot afford to pay for private care. When governments invite companies to influence public health, as when food corporations advise on healthy eating in the UK, obesity levels still rise, indicating that the profit motive can counteract and not guarantee public health. Yet advocates of the market, including the World Bank, pressure governments into privatising health-related state-run services, from water to hospitals. Nestlé is criticised for promoting high-sugar diets, and baby milks that harm and kill babies in poorer countries, ${ }^{44}$ and it is the world's largest vendor of bottled water. The Chief Executive declared that water is not a human right but a commodity to be sold, and that private companies organise water supplies most effectively. ${ }^{45}$ However, this policy ends with the poorest people paying the most for water, bought in bottles and buckets. Around the world, private companies channel their profits to shareholders instead of into repairing and improving the services (Hildyard, 2014). Around one billion people lack safe clean water, and two billion people lack sanitation, which especially jeopardises child health and survival (Oxfam International, 2014; UNICEF 2014).

The market claims to guarantees excellence by promoting free competition. Yet in reality the market is not free but highly subsidised by states, such as through PPPs (Public Private Partnerships) to build and run hospitals. The UK has the most PPPs in the world (Hildyard 2014). They yield 13-25 per cent annual profit, and English health services are becoming bankrupt through by having to pay over decades up to six times the original cost of building each PPP hospital. PPPs exist in over 134 disadvantaged countries. For example, in Lesotho, the extremely poor, landlocked state within South Africa, more than half of the approximately two million people are aged under-25, and around one third under-15 years. ${ }^{46}$ Although 99 per cent of the costs of the new PPP hospital in Lesotho were paid from government funds, all profits go to the private sector that paid only one per cent: a group of private equity, hedge fund and venture capitalists; private banks and pension funds; lawyers who devised the decades-long contracts; and there are the bribes paid to government officials (Hildyard 2014). The people of Lesotho desperately need healthcare staff more than trophy buildings and debts.

Second on philanthropy, advocates of the market say that philanthropy safeguards child health by filling in any gaps left by the market. For centuries, charities have protected, rescued and provided for children, have set up imaginative new services and have campaigned valiantly for greater practical respect for children's rights and health. Charities such as the Children's Rights Alliance for England ${ }^{47}$ in detailed annual reports publicly challenge the government's record on respecting or violating children's rights. Child to Child works with children to promote their health-related rights. In Northern Uganda, a twinning programme paired a child with and a child without disability. Within a year nearly four times as many disabled children had enrolled in school. One disabled child said: "My twinning buddy reads the billboard for me, we play games; he is my guide, I love my friend!" ${ }^{48}$ Children help to run a radio program in Sierra Leone that supports Ebola-affected children and enables them to talk "about their knowledge, attitudes, practices, beliefs, hopes and dreams" 
in vernacular languages. "With Ebola particularly; people don't trust top-down information [and] the official government lies...they think there's a conspiracy," commented a radio director. Instead, the people prefer known and trusted local adults' and children's voices to convey health-related information. ${ }^{49}$

On a much larger scale, Bill and Melinda Gates are praised for their philanthropy and their work has saved many lives, although their Foundation does also pose problems. It is not accountable or democratic and can bypass and overrule governments. Bill Gates is proud of his record of forming policy and influencing governments and UN agencies, such as by forcing the privatising of healthcare and schools (Bakan 2012; Ball 2013). He sees privatised water supplies, as the solution for the 2.5 billion people without sanitation, and to prevent the 700,000 child deaths each year from diarrhoea. ${ }^{50}$ The Foundation promotes PPPs and partners the pharmaceutical company GlaxoSmithKlein. ${ }^{51}$ They have centralised control of the world public health market of vaccines, believing that they benefit the world's children, despite charging UNICEF much higher prices for the vaccines. Gates makes grants for healthcare and research largely to USA and UK companies, and gives direct grants to Africa only on condition that related public health services are sold and privatised. There are doubts about his high-technology, expensive, minority world remedies for majority world problems. These remedies can increase debt and dependence in the poorest countries through "venture philanthropy", which is invested in projects that will return profits. ${ }^{52}$ The Gates Foundation is backed up by massive investments in fossil fuel industries, and is criticised for supporting these industries when their emissions increase many of the problems that the Foundation aims to relieve. ${ }^{53}$

Philanthropy has the drawbacks that grants are made on the choice and whim of the donors, and can be withdrawn at any time so that long-term, fair, coordinated planning is not possible. Some groups are favoured, such as in lavish funding for "white" cell research into childhood leukaemia, while others are neglected, such as the "black' cells of childhood sickle cell or thalassaemia.

Commercial philanthropy, supported by the "celebritocracy" treats poverty as a problem to solve with aid. Yet for 35 years poverty has steadily increased. The Gates are among the 67 people in the world (in 2015) who had more wealth between them than the poorest 50 per cent, over 3.5 billion people, and each year the tiny elite grows richer and the majority grows poorer ${ }^{54}$ Philanthropy can wrap a seemingly generous and glamorous veil around the gross inequality that causes the problems philanthropy seeks to relieve, and the veil helps to defuse critical analysis, protest and work on alternative solutions.

The third policy is healthcare organised by governments, which liaise with businesses and charities but are the primary providers and organisers. Only elected governments can promote the social justice and equality that correlate with health: healthy children including the poorer ones thrive in more equal societies, whereas extreme differences between rich and poor undermine almost everyone's health and wellbeing among both richer and poorer groups (Wilkinson and Picket (2009). The present great need, suffering and premature death of so many children can only partly be remedied by providing more resources and healthcare. Economic structures that increase inequality and ill health will have to change, and this will depend on international action by governments that will have to cooperate if they are to prevent and reduce pollution, carbon emissions, armed conflict, migration away from violence and destitution, and other major problems that harm health (Klein, 2014). 
Very many more young people need to join the healthcare professions, teaching and research. Private healthcare companies greatly benefit from these vital workers, but seldom fund their training, which governments have to do. Investing in education generally promotes health when average standards of children's health rise with every extra year their mothers spent at school or college (Boyden and Bourdillon, 2012).

All these measures involve reversing current dominant policies to "shrink the state" and privatise healthcare and other services to be run for profit by commercial companies. Another current policy attempts to placate tax payers by saying that state health and welfare services should favour those who have contributed most in taxes to support them. Yet this punishes children who have not yet had the chance to pay income tax, and it is a false economy when societies need a healthy future workforce.

The global Millennium Development Goals (MDGs) have had mixed effects. MDG 4 is to reduce by two thirds, between 1990 and 2015, the mortality rate of children aged under-five years. The goal has not been met, though great progress has been made, especially in Rwanda where it is estimated 509,000 children's lives have been saved since $2000 .^{55}$ Agnes Binagwaho, the Minister of Health and a former paediatrician set up a national system of 45,000 care workers who record their activities and the outcomes on their mobile phones, and are paid by results. Unlike most countries, Rwandan policy concentrated on reaching every child and family, however hard it was to make contact with them, when working to reduce the four main causes of child death: malaria, pneumonia, TB and diarrhoea. The example shows the vital role of government authority and planning, actively taking healthcare out to the people in order to create and sustain far-reaching change.

Brazil has rapidly rolled out primary-care services across the entire country through pioneering health councils, though with mixed support from the World Bank. The Bank claims to advocate a rights-based "universal and equitable health coverage" but it fails to reach many poor communities and its major policies still promote profitbased industry and privatised public services. ${ }^{56}$ Protests are growing in all continents against these policies, such as in the Indian Right to Food campaign involving many groups including child rights organizations. They all believe "everyone has a fundamental right to be free from hunger and that the primary responsibility for guaranteeing basic entitlements rests with the state". ${ }^{57}$ Aboriginal communities are campaigning for access to healthcare and action on causes of ill health. Each country tackles their health-related rights in different local ways, though in a shared vision "of equity and justice, and imbued with the urgency that the present global health crisis demands". 58

In conclusion, the driving force behind child health and illness, and whether children's health-related rights are honoured or violated, is economics (reviewed in detail in Alderson, 2016). Children become patients when adults are willing and able to pay for their treatment, and when it is profitable for companies to sell treatments. Although children's lives are precious to their family, in the market they may not count as worth the cheapest healthcare. The greatest threat to children's healthrelated rights is not lack of existing knowledge or resources, but the decisions made by electorates, governments and global agencies such as the World Bank, when they choose not to invest or not to invest in child health. Politics and economics, more than doctors, determine when children can be regarded and treated as patients in need of healthcare. 
Yet countries that do support children's healthcare face hard questions about how far the rights extend. A right to very costly cancer care? To repeated organ transplants? To forcing care on extremely ill babies and children who might prefer to die in peace? To a cocktail of medications for behavioural disorders that may be cured through changes in the child's life style and social context? Is it right to spend over a million dollars on one child's care, when so many children die for lack of simple cheap remedies and protections?

The UNCRC does not provide definite answers but it does offer a rich resource for addressing these questions, and for involving children and young people in these debates. The aim is to balance children's individual and collective rights and best interests, and to distribute resources, including healthcare practitioners, far more equally around the world. Children's ill health can be a warning of problems that threaten many of their rights, problems such as poverty, inequality, undue stress and pollution.

"Contraction and convergence" has been recommended as a way for the rich world to contract its excess consumption and waste, and gradually to converge with standards of consumption in the poor world, until everyone has more equal shares of the resources on the finite planet (Meyer 2000). This idea might have to be applied to health care in order to respect children's rights equally, and to support work in the world's poorest countries, where the burden of disease is the greatest. It is also vital to alter global policies away from health-destroying ones towards health-promoting ones.

\section{References}

African Union. (1990) African Charter on the Rights and Welfare of the Child. Addis Ababa: African Union.

Alderson, P. (1993) Children's Consent to Surgery. Buckingham: Open University

Press.

Alderson, P. (2012) Children's consent and 'assent' to health care research, in M. Freeman (ed) op. Cit., 174-189.

Alderson, P. (2013) Childhoods Real and Imagined. London: Routledge.

Alderson, P. (2014) Children as patients. In Melton, G., Ben-Arieh, A., Cashmore, J., Goodman, G. and Worley, N. (eds) The Sage Handbook of Child Research, London, California, New Delhi, Singapore: Sage, 100-117.

Alderson, P. (2016) The Politics of Childhoods Real and Imagined. London:

Routledge.

Alderson, P. and Morrow, V. (2010) The Ethics of Research with Children and Young People: A Practical Handbook. London: Sage.

Alderson. P., Hawthorne. J. and Killen, M. (2005) Are premature babies citizens with rights? Provision rights and the edges of citizenship, Journal of Social Science, 9:8090.

Alderson, P., Sutcliffe, K. and Curtis, K. (2006) Children's consent to medical treatment. Hastings Center Report 36: 25-34.

APA - American Psychiatric Association. (2013) DSM-5, Diagnostic and Statistical Manual of Mental Disorders. Washington DC: APA.

Bakan. J. (2012) Childhood Under Siege. London: Vintage.

Ball, S. (2013) Education, Justice and Democracy; The Struggle over Ignorance and Opportunity. London: CLASS. 
Bourke, J. (2014) Wounding the World: How Military Violence and War-Play Invade our Lives. London: Virago.

Boyden, J. and Bourdillon, M. (eds) (2012) Childhood Poverty: Multidisciplinary Approaches. Basingstoke: Palgrave Macmillan.

Bryant, T. And Raphael, D. (2015) Introduction to the special issue on the political economy of children's health, International Journal of Child, Youth and Family Studies, 6, 181-5.

Buchanan, A. (2015) The Heart of Human Rights. Oxford: Oxford University Press. Carty, T. (2012) Extreme Weather, Extreme Prices: The Costs of Feeding a Warming World. Oxford: Oxfam.

Clarke, A. and Ticehurst, F. (2006) Living with the Genome: Ethical and Social Aspects of Human Genetics. Basingstoke: Palgrave Macmillan.

Committee on the Rights of the Child (2013) General comment No. 15 on the right of the child to the enjoyment of the highest attainable standard of health (art. 24).

Geneva: UNCRC, http://www.crin.org/docs/CRC-C-GC-15 en-1.pdf .

Coyne, I., Amory, A., Lieman, G. And Gibson, F. (2014) Children's participation in shared decision-making: Children, adolescents, parents and healthcare professionals' perspectives and experiences, European Journal of Oncology Nursing, June

Doman, P. and Woodhead, M. (2015) How Inequalities Develop through Childhood. Florence: Unicef Innocenti.

EC - European Council. (1950) European Convention on Human Rights. Brussels. Evans, J., Meslin, E. Marteau, T. and Caulfield, T. (2011) "Deflating the genomic bubble", Science, 331(6019): 861-2.

Freeman, M. (2012) Law and Childhood Studies. Oxford: Oxford University Press. Herring, J. (2012) Vulnerability, children and the law, in Freeman (ed) op. Cit., 24363.

Hildyard, N. (2014) Public-Private Partnerships, Financial Extraction and the Growing Wealth Gap: Exploring the Connections. Sturminster Newton: Cornerhouse. Honwana, A. and De Boeck F. (eds) (2005) Makers and Breakers: Children and Youth in Postcolonial Africa. Oxford: James Curry.

lannott,i L., Trehan, I. and Manary, M. (2013) Review of the safety and efficacy of vitamin A supplementation in the treatment of children with severe acute malnutrition, Nutrition Journal, 12:125.

Khor, M. (2006) Medical brain drain hits poor nations, Third World Network, http://www.twnside.org.sg/title2/gtrends99.htm.

Klein, N. (2014) This Changes Everything: Capitalism vs. the Climate. London: Allen Lane.

Kolch, M., Ludolph, A., Plener, P., Fangerau, H., Vitiello, B. and Fegert, J. (2010) Safeguarding children's rights in psychopharmacological research: Ethical and legal issues, Current Pharmacological Design, 16 (22): 2398-406.

Lewis, J. (2015) Culture, Media and Human Violence: From Savage Lovers to Violent Complexity. London: Rowman and Littlefield.

Marmot, M. and colleagues. (2013) Review of Social Determinants and the Health Divide in the WHO European Region. London: Institute of Health Equity, UCL and WHO.

Meyer, A. (2000) Contraction and Convergence: The Green Solution to Climate Change. Totnes: Green Books.

Mills, C. (2012) "Special" treatment, "special" rights, in Freeman (ed) op. Cit., 438455. 
Minton, A. (2012) Ground Control: Fear and Happiness in the Twenty-first-century City. London: Penguin.

Nadesan, M. (2010) Governing Childhood into the 21st Century: Biotechnologies of Childhood Management and Education. New York: Palgrave Macmillan.

Nuremberg Code (1947))

http://ori.dhhs.gov/education/products/RCRintro/c03/b1c3.html.

Oxfam International (2014) A Sign of Things to Come? Examining Four Major

Climate-related Disasters, 2010-2013, and their Impacts on Food Security. Oxford:

Oxfam International.

Parsons, T. (1951) The Social System. Glencoe III: Free Press.

Pearce, F. (2007) When the Rivers Run Dry: What Happens When our Water runs out? London: Transworld.

Pearce, F. (2012) The Landgrabbers: The New Fight over Who Owns the Earth.

London: Transworld.

Pembrey, M., Bygren, L., Kaati, G., et al. (2006) Sex-specific, male-line trans-

generational responses in humans, European Journal of Human Genetics, 14: 15966.

Pinker, S. (2011) The Better Angels of Our Nature: Why Violence Has Declined. New York: Viking.

RCPCH - Royal College of Paediatrics and Child Health. (2000) Guidelines on the ethical conduct of medical research involving children, Archives of Disease in Childhood, 82(2): 177-82.

Rose, H. and Rose, S. (2014) Genes, Cells and Brains: The Promethean Promise of the New Biology. London: Verso.

Ross, L.F. (2006) Children in Medical Research: Access versus Protection. New York: Oxford University Press.

Roy, A. (2014) Capitalism: A Ghost Story. London: Verso

Sloth-Nielsen, J. (2012) Modern African Childhoods: Does the Law Matter? In

Freeman (ed) op.cit., 117-132.

Stevenson, B. (2015) Just Mercy: A Story of Justice and Redemption. London:

Scribe

UN - United Nations. (1948) Universal Declaration of Human Rights. New York; UN.

UN - United Nations. (1989) Convention on the Rights of the Child (UNCRC). New

York: UNICEF, www.unhchr.org.

UN Secretary General's Study (2006) Violence Against Children. New York: UN. UNICEF. (2014) Every Child Counts: The State of the World's Children 2014 in numbers. New York: UNICEF.

Wang, W., Oveku, S., Luo, Z. Et al. (2013) Hydroxyurea is associated with lower costs of care of young children with sickle cell anemia, Pediatrics, 2 September [Epub ahead of print]

Willow, C. (2015) Children Behind Bars. Bristol: Policy.

WHO - World Health Organization (1946) definition of health adopted by the International Health Conference. New York: WHO.

WMA - World Medical Association (1964/2013) Declaration of Helsinki. FernayVoltaire: WMA.

Wilkinson, R. and Pickett, K. (2009) The Spirit Level. Harmondsworth: Penguin. Woodhouse, B. (2010) Hidden in Plain Sight: The Tragedy of Children's Rights from Benjamin Franklin to Lionel Tate. Princeton NJ: Princeton University Press 


\section{Notes}

1 Taylor-Robinson, D., Whitehead, M. and Barr, B. (2014) Great leap backwards, British Medical Journal, 349 doi: http://dx.doi.org/10.1136/bmj.g7350, see also www.cpag.org.uk; www.gov.uk/government/publications/state-of-the-nation-2014-report; www.unicefirc.org/publications/733.

2 Taylor-Robinson, D., Bowles, .J, Barr, B. and Whitehead, M. (2014) Child mortality in the UK, Lancet, 384:1923.

3 www.cles.org.uk/wp-content/uploads/2014/09/Due-North-Report-of-the-Inquiry-onHealth-Equity-in-the-North-final1.pdf.

${ }^{4}$ Shown by a 15-year long study in India, Ethiopia, Peru and Vietnam, www.younglives.org.uk

${ }^{5}$ National Research Council and the Institute of Medicine (2013)

https://www.iom.edu/Reports/2013/US-Health-in-International-Perspective-Shorter-LivesPoorer-Health.aspx .

${ }^{6}$ Kaiman, J. (2013) Healthcare in China, Observer, 21 July.

7 For example http://www.waronwant.org/news/press-releases/18116-rogue-firmsnominated-for-badge-of-shame, April 2014.

8 Valo, M. (2013) Pesticide fears to French West Indies, Guardian Weekly, 10 May.

9 WHO (2015) http://www.who.int/heli/risks/climate/climatechange/en/; http://www.policymic.com/articles/21419/climate-change-kills-5-million-people-every-yearhere-s-how, 2012.

${ }^{10} \mathrm{http}: / /$ climate.nasa.gov/effects/ June 2015.

$11 \mathrm{http}: / /$ www.antislavery.org/english/slavery today/child slavery/default.aspx; UK Human

Trafficking Centre, part of the National Crime Agency. Report in 2012.

12 http://www.who.int/mediacentre/factsheets/fs358/en/ May 2015.

${ }^{13}$ Hickel, J. (2015) The death of international development, Red Pepper, 22-5.

14 World Health Organisation (2015)

http://www.who.int/heli/risks/climate/climatechange/en/.

15 Goldenberg, S. (2013) Why global water shortages pose threat of terror and war, Observer, 9 February.

16 http://www.eurekalert.org/pub_releases/2015-02/tca-wma022215.php

17 http://www.unicef.org.uk/latest/news/a-million-Syrian-children-now-refugees/ 23 August 2013.

18 https://www.caat.org.uk/resources/countries/saudi-arabia. .

$19 \mathrm{http}: / /$ www.gfintegrity.org/issue/illicit-financial-flows/.

20 http://www.oxfam.org/en/campaigns/why-we-need-global-arms-trade-treaty; www.caat.org.uk.

${ }^{21} \mathrm{http} / / /$ reason.com/archives/2002/03/01/the-politics-of-dead-children/

${ }_{22}$ http://www.globalresearch.ca/the-children-of-iraq-was-the-price-worth-it/30760.

23 www.bipolarchild.com.

24

http://www.youngminds.org.uk/news/blog/2777 large rise in uk admissions for teenage e ating disorders 3 June 2015.

25 There is concern about inadequate services and incomplete, out-of-date records. By 2014, the most recent national report was still Costello, J. et al. (2003) Prevalence and development of psychiatric disorders in childhood and adolescence, Arch. Gen. Psychiatry, 837-44; House of Commons Health Committee (2014) Third Report: Children's and Adolescents" Mental Health and CAMHS. London: House of Commons. http://www.publications.parliament.uk/pa/cm201415/cmselect/cmhealth/342/34202.htm. 
${ }^{26} \mathrm{https}$ ://www.mentalhealthtoday.co.uk/cuts-to-camhs-creating-problems-now-and-in-thefuture.aspx, 1 July 2014.

27 http://www.youngminds.org.uk/news/blog; www.childline.org.uk; Royal College of

Nursing, http://www.bbc.co.uk/news/health-30150747, 10 February 2015.

28 House of Commons Report (2014) see above.

29 http://www.telegraph.co.uk/comment/letters/10171926/Children-and-legal-aid.html, 11 July 2013.

$30 \mathrm{http}: / / w w w . c b s n e w s . c o m / n e w s /$ study-1-in-4-kids-go-without-health-care/; http://www.childrenshealthfund.org/sites/default/files/WhitePaper-May2007-FINAL.pdf.

31 http://rall.com/2013/10/07/obamacare-i-have-the-dish;

http://www.huffingtonpost.com/2013/11/08/obamacare-

states_n_4234441.html?utm_hp_ref=obamacare; http://www.wnd.com/2013/09/obamacareleaves-500000-kids-without-insurance/.

32 Symons, X. (2013) Outcry in America over prohibitive cost of birth, report from data analytics company Truven, bioedge@aweber.com.

33 US Top of List for First-Day Deaths in Rich Nations, http://news.nationalgeographic.co.uk/news/2013/13/130508-united-states-babies-newbornmothers-infant-mortality-save-the-children/.

34 India Drug-makers Launch Coalition to Stop Big Pharma from Trashing Generics", 26

June 2014, http://www.pharmamanufacturing.com/industrynews/2014/india-drugmakerslaunch-coalition-generics-rep/.

35 http://www.independent.co.uk/news/world/asia/glaxosmithkline-chiefs-confess-to-bribingchinese-doctors-8703390.html, 11 July 2013.

36 https://www.opendemocracy.net/5050/amber-huff/ebola-exposing-failure-of-internationaldevelopment.

37 Boseley, S. (2014) Fears that maternal death rates in Sierra Leone, Liberia and Guinea could increase 20-fold as health facilities collapse, Guardian, 10 November;

www.dec.org.uk.

$38 \mathrm{http} / / /$ www.bbc.co.uk/news/world-africa-25869838.

$39 \mathrm{http}: / /$ sicklecellsociety.org/

40 Angastiniotis, M., Kyriakidou, S. Hadjiminas, M. (1986) How thalassaemia was controlled in Cyprus, World Health Forum, 291-97.

41 Gillick v. Wisbech \& W Norfolk AHA [1985].

42 Boseley, S. (2010) Nigeria: Drug trial tale of "dirty tricks", Guardian Weekly, 17

December; http://www.cbsnews.com/8301-505123 162-42846951/pfizers-nigeria-scandaldoctors-without-borders-stirs-the-pot-to-little-effect/, 5 January 2011 (accessed 7 January 2013); http://www.bbc.co.uk/news/world-africa-14493277 1 August 2011, accessed 1 June 2015.

43 An on-line search for "medical research fraud" found over 12 million hits.

44 http://new.babymilkaction.org/ June 2014.

45 https://www.youtube.com/watch?v=4C29 U0Ksao 26 Aril 2013.

$46 \mathrm{http://www.indexmundi.com/lesotho/demographics} \mathrm{profile.html.}$

47 www.crae.org.uk.

48 www.childtochild.org.uk, April 2015.

49 www.childtochild.org.uk, 5 June 2015.

50 http://www.gatesfoundation.org/What-We-Do/Global-Development/Water-Sanitation-andHygiene.

51 GSK paid \$3 billion fines for fraud in July 2012, http://www.bbc.com/news/world-uscanada-18673220. 
52 http://blogs.edweek.org/teachers/living-in-

dialogue/2012/07/the gates foundations leverage.html 4 July 2012.

$53 \mathrm{http} / /$ www.theguardian.com/environment/video/2015/apr/30/hi-bill-keep-it-in-the-groundcampaign, 30 April 2015.

54 The Wealth Report 2014, http://www.knightfrankblog.com/wealthreport/newsheadlines/onwards-and-upwards/.

55 Inquiry, BBC World Service, 26 April 2015.

56 Global Health Watch (2015) Global Health Watch 4, www.ghwatch.org.

57 http://www.righttofoodcampaign.in/.

58 www.ghwatch.org. 